\title{
Institutionalization of the Czech and Slovenian party system
}

\author{
Alena Klvaňová ${ }^{1}$
}

\begin{abstract}
For the past two decades, the characteristic feature of the Czech Republic and the Republic of Slovenia's party system has been relatively invariable and closed to fundamental change. In both cases, there has been a distortion of the change and its nature which occurred around 2010, when new political entities began to emerge on the political scene. These entities have received support from a large part of the electorate. The reason for the success of the new political parties is mainly related to the dissatisfaction of the Czech and Slovenian public with the political situation and the conviction of citizens about the widespread corruption among public officials. The success of the newly formed entities caused the decline of primarily established parties. The aim of this article is to determine the effect of these changes on the party systems, and simultaneously to answer the question, to what extent both party systems are institutionalized. The answer to this question can be obtained by measuring the extend of institutionalization of party systems based on three criteria, which are incorporation of political parties in the party system, party system stability and quality of party competition.
\end{abstract}

Key words: Party system, Czech Republic, Republic of Slovenia, political party, indicators of measuring the degree of institutionalization, stability, degree of institutionalization of party system.

\section{INTRODUCTION}

The Czech Republic and Slovenia are Central European countries which share the same past in some respects. Both countries have experienced a totalitarian regime. After the fall of it, they had to learn to work with democratic elements. One of them is the pluralism of political parties. The first parliamentary elections in observed countries were held in 1990. The main role was played by one dominant group, the Civic Forum (Občanské fórum, $O F$ ) in the Czech Republic and the DEMOS coalition in Slovenia. In the future, these political groupings have disappeared, but new political parties were formed on the political scene. These became the basic and invariable element of the Czech and Slovenian party system, in which the new political entities did not interfere for a long time.

In the last few years however, there was a turning point in both countries that brought a significant transformation of the Czech and Slovenian party system leading to its instability. On the political scene, new parties appeared. Their

1 Mgr. Alena Klvaňová, Faculty of Law, Department of political science and societal sciences, Palackeho University Olomouc, Czech Republic and Masaryk University in Brno, Czech Republic. e-mail:klvanova.alena@seznam.cz. 
success was unprecedented in the last two parliamentary elections and caused a decline in electoral support for the established political parties. In the Czech Republic, these were TOP 09 and the Public Affairs Party (Věci veřejné, $V V$ ) who appeared new on the political scene in 2011. They were followed by ANO 2011 and the Tomio Okamura's Dawn of Direct Democracy (Úsvit př́mé demokracie Tomia Okamury) in 2013. These subjects experienced unprecedented success during elections, which had an impact on the decline in electoral support for the two strongest political parties, the Czech Social Democratic Party (Česká strana sociálnè demokratická, ČSSD) and the Civic Democratic Party (Občanská demokratická strana, ODS). In the case of Slovenia, we can speak of a similar tendency, the rise of newly formed political parties before the elections in 2011 and 2014 and the decrease of established political parties. The newcomers on the Slovenian political scene were the Zoran Janković List - Positive Slovenia (Lista Zorana Jankovića - Pozitivna Slovenija, LZJ-PS) and the Citizen's list of Gregor Virant (Državljanska lista Gregorja Viranta, DLGV) in 2011. They were followed by the Party of Miro Cerar (Stranka Mira Cerarja, SMC), the United Left (Združena levica, ZL) and the Alliance of Alenka Bratušek (Zavezništvo Alenke Bratušek, ZaAB) in 2014. The success of the newly formed parties caused the decline mainly of the party, Social Democracy (Socialni demokrati, SD).

The dissatisfaction of Czech and Slovenian public with the political situation resulted mainly from intra-party contradictions and convincing people about the widespread corruption among public officials; and as such was the main reason for the change of voting behavior among a large part of the Czech and Slovenian electorate who decided to vote for new political entities and to punish the established political parties and their elites.

Considering the events in the development of the Czech and Slovenian party system in the past few years, this article aims to answer the question, to what extent are both party systems institutionalized. The answer to this question can be obtained by measuring the rate of institutionalization of party systems based on the model of the indicator consisting of three criteria which were chosen from a wide range of criteria developed by the author Vlastimil Fiala (Fiala 2015). To assess the degree of institutionalization of the Czech and Slovenian party system, it was decided to use the criterion of incorporation of political parties in the party system, the party system stability and quality of party competition. These criteria are first defined and then applied on the example of the Czech and Slovenian party system. Before this a focus on the theoretical basis for the analysis of party systems is needed. 


\section{THEORETICAL BASIS FOR THE ANALYSIS OF PARTY SYSTEMS}

A research of political parties and party systems has become a very important segment of the political science. At this point, it is advisable to mention that according to Italian African Giovanni M. Carbone, the party systems can be examined in several approaches such as the sociological, electoral, institutional and morphological approach (Carbone 2007, p. 11-16). In view of the fact that we focus on the question of the stability of the Czech and Slovenian party system, it is not surprising that the framework of the research is to be focused on the institutional approach. First, before analyzing the Czech and Slovenian party system, it is necessary to focus briefly on the fact, how can the party system be understood and how to define it.

\subsection{The definition of party system}

At the beginning, it is necessary to be noted that the concept of a party system was dealt with by a number of political scientists, which shows the fact that there is not a uniform definition. It is also necessary to present the most famous political scientists who have focused their attention to the concept of party systems. These include Maurice Duverger, Jean Blondel and Giovanni Sartori whose book Parties and Party Systems has become one of the turning works across political science. In his book, Sartori says that the party system is " $a$ system of interactions resulting from inter-party competition. This means that the system we are talking about is related to the mutual relationship between the parties, to the way each party is a function (in the mathematical sense) of the other parties and responds competitively or otherwise to the other parties" (Sartori 2005, p. 55). It can be said that Sartori's definition is still accepted as one of the most comprehensive and contains two important criteria of the party system. These are the interactions between the various political parties and their competitiveness in the elections. From Sartori's definition it can be deduced that the party system must consist of at least two units, otherwise the interactions would not have been possible which means no competition between them. In connection with Sartori's definition it is possible to say that its numerous variations in contemporary scientific publications arise. The American political scientist Scott Mainwaring can be mentioned. According to him, the party system is a set of political parties that interact in fixed patterns (Mainwaring 1999, p. 24). According to these definitions we can imagine what party system includes. But there still remains a question of which political parties form the political party system. In this respect, within the analysis we consider the model 
of Euro-American party system, by which it consists only of parts with a long parliamentary representation (Fiala 2015, p. 65). When measuring the degree of institutionalization, this definition will be followed and only the parliamentary political parties will be taken into account, because it is considered that just these have a decisive influence on the form and stability of the party system.

\subsection{The theoretical concept of institutionalization}

The issue of institutionalization is currently one of the key research topics of political parties, and its roots go deep into the past. Practically, since the beginning of human society the research of institutions was in the spotlight of various researchers. We can generally say that the fundamentals of the current research of institutionalism were put by the American political scientists Scott Mainwaring and Timothy R. Scully, who focused in their initial work on the institutionalization of party systems in Latin American countries, while providing a framework for the analysis of the degree of institutionalization according to four criteria. These are voter volatility which is closely related to the stability of inter-party competition, the degree of social incorporation of political parties in society, acceptance of elections as a legitimate source of political power and the degree of party organization, or the quality of the organizational structures of political parties (Fiala 2015, p. 68). At this point, the observation of Maximilian Strmiska needs to be mentioned. He argues against Mainwaring's approach that due to his definition of the party system, authors use only one criterion in exploring the institutionalization of the system, which is the stability of inter-party competition, because it is the only one which is directly related to patterns of political parties interactions. According to Strmiska, the remaining three criteria should not be assessed in the context of predispositions for the system functioning (Strmiska 2000). Notwithstanding the foregoing, we did not decide to reject Mainwaring and Scully methodology but partly use it for the purposes of our analysis. However, we must mention that the measuring of the institutionalization of the Czech and Slovenian party system is based mainly on the work of V. Fiala about the institutionalization of the Mozambican political parties and the party system, in which the author works not only with indicators formulated by the aforementioned authors, but he also uses his own criteria or the ones extracted from various literature (Fiala 2015).

\subsection{The criteria of institutionalization of party systems}

As already indicated above, the institutionalization of party systems can be 
measured using various criteria. Based on our depth analysis we concluded that there are relevant criteria below to assess the degree of institutionalization of the Czech and Slovenian party system. We define them in the next section and then we demonstrate them on the example of the Czech and Slovenian party system.

Table 1: Major and minor criteria of institutionalization of party systems

\begin{tabular}{|l|l|}
\hline Major criteria & Minor criteria \\
\hline $\begin{array}{l}\text { Incorporation of political parties } \\
\text { in the party system }\end{array}$ & $\begin{array}{l}\text { Long-term support of the parliamen- } \\
\text { tary political parties }\end{array}$ \\
\cline { 2 - 2 } & Support of the presidential outsiders \\
\hline Stability of party competition & $\begin{array}{l}\text { Long-term volatility of the political } \\
\text { parties in parliamentary elections }\end{array}$ \\
\hline Quality of party competition & Regularity in competition series \\
\hline
\end{tabular}

Source: Fiala 2015, p. 248

Before one begins with the definition of individual indicators, one should first deal with several methodological problems. The first of them is the question about the origins of institutionalization research of party systems. In the case of the Czech Republic, it is decided to examine the party system since the first elections to the Chamber of Deputies in 1996, since this time it can be considered as relatively invariable and already crystallized; in the case of Slovenia, one may put the beginning of the party system research in 1992, when the country held its first elections to the National Assembly. Another important methodological question is, which parties need to be examined in the analysis. We have already said above that we will consider the Euro-American model, according to which, the party system is composed only of parliamentary parties. At this point, however, we must add that particularly in the context of electoral support and the volatility we examine only the political parties with a long parliamentary representation. Although the new political parties in the Czech and Slovenian Parliament were detected, especially in recent years, they did not defend their parliamentary representation in the next elections, therefore we believe that it makes no sense to pay more attention to them.

The first criterion this article focuses on will be the incorporation of political parties in the party system, under which we will be interested in the electoral support of the parliamentary political parties. At this point, we must emphasize that our aim will be mainly to evaluate the stability of the average electoral 
support for the political parties with long-term parliamentary representation, because we assume that the party system is characterized by larger stability, if the established political parties are able to maintain long-term support of their voters. The long-term electoral support is calculated in the way that we count up the electoral gains of the established parliamentary parties in all election series and then we average them. For the score of electoral support the model assembled by V. Fiala is used. It looks as follows:

- $3,0=$ more than $80 \%$ votes

- $2,5=79-70 \%$ votes

- $2,0=69-60 \%$ votes

- $1,5=59-50 \%$ votes

- $1,0=$ less than $50 \%$ votes (Fiala 2015, p. 74)

To evaluate the incorporation of political parties in the party system, the indicator of support of outsiders in the presidential election, which is related to voting for candidates of non-parliamentary parties is used. The hypothesis of the authors S. Mainwaring and Torcal Mariana has convinced us to select this indicator. They are of the opinion that the high voter preferences of parliamentary political parties candidates are proof of their incorporation, but too high support of independent candidates or candidates for non-parliamentary parties, both of which the authors described as the outsiders, is the evidence of no incorporation of political parties in society (Mainwaring, Torcal 2006, p. 216). At this point, it must be mentioned to take into account only the results of the presidential election in the first round, because it is only the first round which can answer the question of whether voters consider the party membership of the presidential candidate. At the same time, it must be added that in this respect, a parliamentary party is considered to be a party that has parliamentary representation during the election period. As an outsider is therefore considered a candidate of the party which has in historical perspective exceeded the compulsory electoral bound, but at the time of the presidential elections it was not a parliamentary party. The indicator model of presidential outsiders support that we use to obtain the final value looks as follows:

- $3,0=$ less than $5 \%$ votes

- $2,5=6-9 \%$ votes

- $2,0=10-19 \%$ votes

- $1,5=20-29 \%$ votes

- $1,0=30 \%$ and more votes (Fiala 2015, p. 75) 
The most commonly used indicator of the stability of the party system will be also included into this analysis. It is the voter volatility renovated by Mogens Pedersen. The main ambition of Pedersen's index of the electoral volatility is to describe the fluctuation of the electoral support among the individual political parties in two consecutive elections. According to the above mentioned index, the voter volatility is calculated by counting up of all the percentage changes in gains of political parties and then dividing that number by two (Cabada, Hloušek, Jurek 2013, p. 125-126). It needs to be add that the voter volatility index is not designed to determine the stability of the electoral behavior of voters, but it is suitable for the research of aggregated support, or rather the stability of the party system. This fact is clarified by Šedo (Šedo 2011, p.64) in his study in that way that it does not matter, from whom the parties have gained their votes, because the two equally strong parties with a $50 \%$ gain in two consecutive elections, when there were only exchanged voters would reach zero index. To illustrate the pattern, Pedersen index is also attached which looks like this:

$$
\mathrm{V}=1 / 2 \sum\left|p_{i t}-p_{i t-1}\right|^{2}
$$

At this point it must be emphasized that in the context of stability of the party competition research will not be reduced only to measure the changes in electoral support between the last two elections, but we calculate the average long-term volatility in all observed election series. As mentioned above, there is a certain methodological problem in a question about which party to include in the calculations. Although the vast majority of authors include all parties in their calculations, irrespective of their size, the focus here is attention only to the volatility of the established parliamentary parties. In this article, the volatility calculations of individual Czech and Slovenian political parties with parliamentary representation is first introduced, whereby then interest in the average long-term volatility of these parties is discussed. To get the score, the model according to the calculation of the stability of the party competition is followed:

- $3,0=0-5 \%$

- $2,0=6-10 \%$

- $1,0=$ more than $11 \%$ (Fiala 2015, p. 228)

Within this research the author takes into account one external criterion of institutionalization of the party system which is the quality of party competition.

2 In Pedersen's index, $p_{i t}$ means a percentage of mandates gained by a party $i$ in observed elections $t$ and $p_{i t-1}$ then means a percentage of mandates for a party $i$ in previous elections. 
It must be claimed that most of the aforementioned experts ignores this criterion in determining the ultimate indicator of institutionalization of the party system. However, this author is of the opinion that the quality of party competition enables also to assess the stability of the party system. In connection with this criterion, we focus in particular on elections regularity. Similarly to V. Fiala, it is assumed the hypothesis that if the country's elections do not take place in regular terms, the party system can be considered as less institutionalized. It should be noted that irregular electoral competition may have a negative impact not only on the political parties, but also on the voters convince that elections are a mean of political power division (Fiala 2015, p. 260). For the score, the slightly modified model created by V. Fiala is used. His model speaks only about causes of irregularities in the election, however, it does not show the percentage range, or rather the number of elections held in irregular terms of the observed parliamentary term. Our adjusted indicator of the regularity of elections is as follows:

- $3,0=100 \%$ regularity of elections

- $2,0=60 \%$ regularity of elections

- $1,0=$ less than $60 \%$ regularity of elections (author)

Based on averaging of all the above partial and total indicators, it is realized to what extent the Czech and Slovenian party system is institutionalized. To determine the overall level of institutionalization the model created by S. Mainwaring and T. Scully is used:

- $3,0=$ high level of institutionalization

- $2,5=$ middle-high level of institutionalization

- $2,0=$ middle level of institutionalization

- $1,5=$ middle-low level of institutionalization

- $1,0=$ low level of institutionalization (Kuenzi, Lambright 2001, p. 443)

In the previous part of this article we have chosen several indicators that we try to apply to the case of Czech and Slovenian party system now and also to answer the question whether both the party systems are institutionalized enough. 


\subsection{Incorporation of political parties in the party system}

In the following article we focus on two main indicators that examine the institutionalization of party systems in terms of their incorporation dimensions in society. First, we look at the electoral support for the political parties in parliamentary elections. Based on the above mentioned reasons, we decided to count the electoral support only of the major political parties with a permanent presence in the Chamber of Deputies, or rather in the National Assembly. In case of the Czech Republic, there are ODS, ČSSD, the Christian and Democratic Union - Czechoslovak People's Party (Křstanská a demokratická unie Československá strana lidová, KDU-ČSL) and the Communist Party Bohemia and Moravia (Komunistická strana Čech a Moravy, KSČM), in calculating the electoral support of Slovenian parties we focus on the Liberal Democratic Party (Liberalno demokratska stranka, LDS), the Slovenian People's Party (Slovenska ljudska stranka, SLS), the Social Democratic Party (Socialdemokratska stranka, $S D S$ ), the Democratic Party of Pensioners (Demokratična stranka upokojencev Slovenije, DeSUS), the Slovenian National Party (Slovenska nacionalna stranka, SNS), SD and the New Slovenia (Nova Slovenija, NSi).

Table 2: Electoral support for the political parties in the parliamentary elections

\begin{tabular}{|l|c|c|c|c|c|c|c|}
\hline $\begin{array}{l}\text { Political } \\
\text { parties }\end{array}$ & $\mathbf{1 9 9 6}$ & $\mathbf{1 9 9 8}$ & $\mathbf{2 0 0 2}$ & $\mathbf{2 0 0 6}$ & $\mathbf{2 0 1 0}$ & $\mathbf{2 0 1 3}$ & Average \\
\hline ODS & 29,62 & 27,74 & 24,47 & 35,38 & 20,22 & 7,72 & \\
\hline ČSSD & 26,44 & 32,31 & 30,20 & 32,32 & 22,08 & 20,45 & \\
\hline $\begin{array}{l}\text { KDU-Č- } \\
\text { SL }\end{array}$ & 8,08 & 9,00 & 14,27 & 7,22 & 4,39 & 6,78 & \\
\hline KSČM & 10,33 & 11,03 & 18,51 & 12,81 & 11,27 & 14,91 & \\
\hline Total & 74,47 & 80,08 & 87,45 & 87,73 & 57,96 & 49,86 & 72,93 \\
\hline
\end{tabular}

Source: author's own table according to the official electoral results (www.volby. $\mathrm{cz})$

As the table above shows, the main Czech political parties reach on average $72.93 \%$ of voter support. The highest value were noticed in 2006 , whereas the lowest ones were noticed in the last elections in 2013. This fact may be rationalized as a departure of voters from traditional parties to the new entities 
on the Czech political scene. As we can see, it is a characteristic feature for the last two elections to depart from the established parties and it is significantly associated with dissatisfaction of voters with the political situation and with the decline of positive connections to political parties. When compared with the table of indicator of parliamentary electoral support we can count the value of 2.5 points for this sub-index.

Table 3: Electoral support of the Slovenian political parties in the parliamentary elections

\begin{tabular}{|l|c|c|c|c|c|c|l|l|}
\hline $\begin{array}{l}\text { Political } \\
\text { parties }\end{array}$ & $\mathbf{1 9 9 2}$ & $\mathbf{1 9 9 6}$ & $\mathbf{2 0 0 0}$ & $\mathbf{2 0 0 4}$ & $\mathbf{2 0 0 8}$ & $\mathbf{2 0 1 1}$ & $\mathbf{2 0 1 4}$ & Average \\
\hline LDS & 23,46 & 27,01 & 36,26 & 22,80 & 5,21 & 1,48 & - & \\
\hline SLS & 8,69 & 19,38 & 9,54 & 6,82 & 5,21 & 6,83 & 3,95 & \\
\hline SDS & 3,34 & 16,13 & 15,81 & 29,08 & 29,26 & 26,19 & 20,71 & \\
\hline DeSUS & - & 4,32 & 5,17 & 4,04 & 7,45 & 6,97 & 10,18 & \\
\hline SNS & 10,02 & 3,22 & 4,39 & 6,27 & 5,40 & 1,80 & 2,20 & \\
\hline SD & 13,58 & 9,03 & 12,08 & 10,17 & 30,45 & 10,52 & 5,98 & \\
\hline NSi & 14,51 & 9,62 & 8,66 & 9,09 & 3,40 & 4,88 & 5,59 & \\
\hline Total & 73,60 & 88,71 & 91,91 & 88,27 & 86,38 & 58,67 & 48,61 & 76,59 \\
\hline
\end{tabular}

Source: author's own table according to the official electoral results (www.dvkrs.si)

When looking at the table above we can see that the major Slovenian political parties reached the average electoral profit from $73.60 \%$ to $91.91 \%$ in the years 1992-2008. Similarly to the Czech Republic, also on the Slovenian political scene, a radical change in the last two elections was noticed. The average voter support has fallen to $58.67 \%$, or rather to $48.61 \%$ in 2014 . It is interesting that these values are almost the same as the average voter support for Czech political parties in 2010 and 2013. The reason for this decrease was also seen the success of the new entities on the Slovenian political scene caused by mistrust of voters against the established political parties. On average, the major Slovenian political parties reach $76.59 \%$ of voter support, the overall index of the Slovenian political parties also reaches the value of 2.5 points.

Another criterion that is used in the article to determine the incorporation of the Czech and Slovenian political parties is linked together with the support of 
so-called presidential outsiders or the candidates of non-parliamentary political parties. At this point, we only remark that during calculations we focus only on the results of the presidential election in the first round because we believe that there is the most obvious partisan vote.

Table 4: The results of the presidential elections in 2013 in the Czech Republic

\begin{tabular}{|l|c|c|}
\hline Candidate & Outsider (yes/no) & $\mathbf{2 0 1 3}$ \\
\hline Zuzana Roithová & YES (KDU-ČSL) & 4,95 \\
\hline Jan Fischer & YES (independent) & 16,35 \\
\hline Jana Bobošíková & YES (SBB) & 2,39 \\
\hline Tat’ana Fischerová & YES (KH) & 3,23 \\
\hline Přemysl Sobotka & NO (ODS) & 2,46 \\
\hline Miloš Zeman & YES (SPOZ) & $24,21 *$ \\
\hline Vladimír Franz & YES (independent) & 6,84 \\
\hline Jiří Dienstbier & NO (ČSSD) & 16,12 \\
\hline Karel Schwarzenberg & NO (TOP09) & 23,40 \\
\hline
\end{tabular}

* elected candidate

Source: author's own table according to the official electoral results (www.volby. $\mathrm{cz})$

Although the direct presidential elections were in the Czech Republic introduced in 2013, and for this reason we only have a limited amount of data, the above mentioned table brings us some interesting findings. First, we find out that a total of nine candidates ran for the post of the President of the Czech Republic, only three of them were not so called outsiders. The results of the presidential election clearly show that the lowest values are reached by the candidate of the non-parliamentary political parties, as well as the candidate of parliamentary political parties. Similar situation is also seen at the best results. Summing up the electoral gains of the individual number of outsiders we come to number $57.97 \%$ and also to conclusion that right these candidates possess greater voter support than the presidential candidates of the parliamentary political parties. On this basis, and especially on the basis of the victory of the outsider Miloš Zeman, we are of the opinion that the Czech voters do not take party membership into 
account in the choice of the President. This way the candidates do not reach the same electoral support as their political party in parliamentary elections. The overall average of the electoral support of the independent candidates reaches $9.66 \%$, so we achieve the result of 2 points, which shows the middle voter support of the candidates of the established parties, and therefore we also reach their incorporation in society.

Table 5: The results of the presidential elections in years 1992-2012 in Slovenia

\begin{tabular}{|l|l|l|l|l|l|l|}
\hline Candidate & $\begin{array}{l}\text { Outsider } \\
\text { (yes/no) }\end{array}$ & 1992 & 1997 & 2002 & 2007 & 2012 \\
\hline Milan Kučan & $\begin{array}{l}\text { YES (inde- } \\
\text { pendent) }\end{array}$ & $63,90^{*}$ & $55,57^{*}$ & - & - & - \\
\hline Ivan Bizjak & NO (SKD) & 21,16 & - & - & - & - \\
\hline Jelko Kacin & NO (DS) & 7,30 & - & - & - & - \\
\hline Stanislav Buser & NO (SLS) & 1,94 & - & - & - & - \\
\hline Darja L. Bebler & YES (SSS) & 1,83 & - & - & - & - \\
\hline Alenka Ž. Slana & YES (NDS) & 1,74 & - & - & - & - \\
\hline Ljubo Sirc & NO (LDS) & 1,51 & - & - & - & - \\
\hline Janez Podobnik & NO (SLS) & - & 18,42 & - & - & - \\
\hline Jožef Bernik & $\begin{array}{l}\text { NO (SDS, } \\
\text { SKD) }\end{array}$ & - & 9,39 & - & - & - \\
\hline Marjan Cerar & $\begin{array}{l}\text { YES (inde- } \\
\text { pendent) }\end{array}$ & - & 7,07 & - & - & - \\
\hline Marjan Poljšak & YES (NSD) & - & 3,22 & - & - & - \\
\hline Anton Peršak & YES (DS) & - & 3,08 & - & - & - \\
\hline Bogomir Kovač & NO (LDS) & - & 2,70 & - & - & - \\
\hline Franc Miklavčič & YES (KSU) & - & 0,55 & - & - & - \\
\hline Janez Drnovšek & NO (LDS) & - & - & $44,40 *$ & - & - \\
\hline Barbara Brezigar & $\begin{array}{l}\text { YES (inde- } \\
\text { pendent) }\end{array}$ & - & - & 30,76 & - & - \\
\hline $\begin{array}{l}\text { Zmago J. Pleme- } \\
\text { niti }\end{array}$ & NO (SNS) & - & - & 8,51 & 19,16 & - \\
\hline Franc Arhar & $\begin{array}{l}\text { YES (inde- } \\
\text { pendent) }\end{array}$ & - & - & 7,59 & - & - \\
\hline
\end{tabular}




\begin{tabular}{|l|l|l|l|l|l|l|}
\hline Franc Bučar & $\begin{array}{l}\text { YES (inde- } \\
\text { pendent) }\end{array}$ & - & - & 3,24 & - & - \\
\hline Lev Kreft & NO (ZLSD) & - & - & 2,25 & - & - \\
\hline Anton Bebler & $\begin{array}{l}\text { NO (De- } \\
\text { SUS) }\end{array}$ & - & - & 1,85 & - & - \\
\hline Gorazd Drevenšek & $\begin{array}{l}\text { YES } \\
\text { (NOVA) }\end{array}$ & - & - & 0,86 & - & - \\
\hline Jure J. Cekuta & $\begin{array}{l}\text { YES (inde- } \\
\text { pendent) }\end{array}$ & - & - & 0,54 & - & - \\
\hline Lojze Peterle & $\begin{array}{l}\text { YES (inde- } \\
\text { pendent) }\end{array}$ & - & - & - & 28,73 & - \\
\hline Danilo Türk & $\begin{array}{l}\text { YES (inde- } \\
\text { pendent) }\end{array}$ & - & - & - & $24,47 *$ & 35,88 \\
\hline Mitja Gaspari & $\begin{array}{l}\text { YES (inde- } \\
\text { pendent) }\end{array}$ & - & - & - & 24,09 & - \\
\hline Darko Krajnc & YES (SMS) & - & - & - & 2,18 & - \\
\hline Elena Pečarič & $\begin{array}{l}\text { YES (inde- } \\
\text { pendent) }\end{array}$ & - & - & - & 0,90 & - \\
\hline Monika Piberl & $\begin{array}{l}\text { YES (Voice } \\
\text { of Women) }\end{array}$ & - & - & - & 0,48 & - \\
\hline Borut Pahor & NO (SD) & - & - & - & - & $39,87^{*}$ \\
\hline Milan Zver & NO (SDS) & - & - & - & - & 24,25 \\
\hline
\end{tabular}

* elected candidate

Source: author's own table according to the official electoral results (www.dvkrs.si)

In the case of Slovenia, we have the opportunity to work with larger amounts of data, because in the country, five direct presidential elections were already organized. When looking at the chart, we find out that in 1992 and 1997, the independent candidate Milan Kučan had a considerable superiority. He won both the elections and became the president of the Republic. The results of so called outsiders also show that in the first election, none of the candidates exceed the limit of $2 \%$ of the votes; in 1997, the limit of $7.1 \%$, except Milan Kučan. The situation changed in 2002 when the post of the president was competed by a total of nine candidates. Five of them, they were the candidates from nonparliamentary political parties and they won $42.99 \%$ of votes together. In this 
case, the presidential candidate of the parliamentary party LDS Janez Drnovšek won these election, which shows the incorporation of the party in the Slovenian society. An interesting situation in terms of the presidential candidates took place in 2007. As you can see, the outsiders had greater support in this election. They won together $80.85 \%$ of votes and so they leave far behind only one candidate for the parliamentary political party. The winner of the presidential elections in 2007 became the independent candidate Danilo Türk who also ran for the president in the 2012 elections, in which he met only two opponents from the others parliamentary political parties. When looking at the chart we can see that all the candidates have achieved high results, but the representatives of parliamentary parties were dominant in these elections. It is necessary to note that the election winner, Borut Pahor, was the candidate of the party that won by more than a half fewer votes than his opponent's political party in the parliamentary elections in 2011. Summing up the total average of the electoral support of the outsiders in five presidential elections, we come to the number of $18.87 \%$ and the score of 2 points, which shows the middle voter support for the candidates of political parties with a long-term parliamentary representation and therefore also their incorporation in society.

\section{STABILITY OF PARTY COMPETITION}

In the following section, we focus on the second criterion of institutionalization of party systems which is the stability of party competition. In this chapter, we work with Pedersen's index of voter volatility, focusing on the electoral volatility only of the major Czech and Slovenian political parties with a longterm parliamentary representation. Our attention is paid not only to the last two elections, but on individual elections in sequence in order to analyze the changes that party systems went through especially in recent years. As we mentioned above, the political parties which failed to maintain their parliamentary representation or the new parties which participated in the elections only once are not included in the calculations. We believe that these calculations would not show the accurate information of how the electoral support of the political parties increases or decreases.

When looking at the table above, you can see that all observed parties achieve important fluctuations. Focusing first on ODS, one can conclude that the most regular electoral support for the party was in 1996-1998, which is an evidence of the low voter volatility of $0.94 \%$. A significant fluctuations, however, occurred in the next parliamentary elections, when the electoral support of the party dramatically increased or decreased, which did not influence the volatility very 
positively and reached the values from $1.63 \%$ to $7.58 \%$. Similarly, the volatility of ČSSD also varies greatly in historical perspective. It exceeded 5\% in 2006 and 2010 because it lost its electoral support $10.24 \%$ of the votes in this period. In case of KDU-ČSL, one can see that the greatest changes in electoral support were in the years 1998-2002 and 2002-2006. The last two elections did not show important fluctuations. It must be emphasized that in 2010 the party achieved only $4.39 \%$ of votes, which caused that this party did not become a parliamentary party in this time. A similar trend as in the previous parties can also be seen in KSČM. But it needs to be said that in KSČM and KDU-ČSL were not so significant changes in terms of volatility index in 2010, as it changed in ODS and ČSSD who lost a considerable part of the electoral support. The causes of this change, we have already mentioned several times, so it is not necessary to pay more attention to them. Briefly, we only summarize that the outflow of C SSD and ODS voters towards the new political entities which did not candidate in previous elections influenced the voter volatility in 2010.

Table 6: Volatility of the Czech political parties

\begin{tabular}{|l|l|l|l|l|l|l|}
\hline $\begin{array}{l}\text { Political } \\
\text { parties }\end{array}$ & \multicolumn{1}{|c|}{$\begin{array}{c}\mathbf{1 9 9 6 -} \\
\mathbf{1 9 9 8}\end{array}$} & $\begin{array}{c}\mathbf{1 9 9 8}- \\
\mathbf{2 0 0 2}\end{array}$ & $\begin{array}{c}\mathbf{2 0 0 2 -} \\
\mathbf{2 0 0 6}\end{array}$ & $\begin{array}{c}\mathbf{2 0 0 6}- \\
\mathbf{2 0 1 0}\end{array}$ & $\begin{array}{c}\mathbf{2 0 1 0}- \\
\mathbf{2 0 1 3}\end{array}$ & $\sum$ \\
\hline ODS & $(-) 0,94$ & $(-) 1,63$ & $(+) 5,45$ & $(-) 7,58$ & $(-) 6,25$ & 4,37 \\
\hline ČSSD & $(+) 2,93$ & $(-) 1,05$ & $(+) 1,06$ & $(-) 5,12$ & $(-) 0,81$ & 2,19 \\
\hline $\begin{array}{l}\text { KDU-Č- } \\
\text { SL }\end{array}$ & $(+) 0,46$ & $(+) 2,63$ & $(-) 3,52$ & $(-) 1,41$ & $(+) 1,19$ & 1,84 \\
\hline KSČM & $(+) 0,35$ & $(+) 3,74$ & $(-) 2,85$ & $(-) 0,77$ & $(+) 1,82$ & 1,91 \\
\hline $\begin{array}{l}\text { Total } \\
\text { volatility }\end{array}$ & 1,17 & 2,26 & 3,22 & 3,72 & 2,52 & 2,58 \\
\hline
\end{tabular}

Source: author's own counting according to the official electoral results (www. volby.cz)

A similar trend can be observed also in 2013. Due to the decline of support for the governmental parties and the success of new parties, from 1996 the total electoral volatility of observed political parties was doubled, which shows the fact that there was a shift of support from at least $40 \%$ of voters. Summing up the aforesaid, we can conclude that the least institutionalized political party is ODS whose volatility in the years $1996-2013$ increased from $0.94 \%$ to $6.25 \%$ and on average, it reaches $4.37 \%$. According to results, it is KDU-Č́SL which is the most 
institutionalized party in the Czech Republic with the average voter volatility of $1.84 \%$. According to calculations of the long-term volatility of four Czech political parties, we have reached an average of $2.58 \%$, which leads to the score of 3 . From the view of volatility, the Czech party system is fully institutionalized, despite the fact that the new political parties are rarely elected to parliament and are not capable to succeed again in the next election.

Table 7: Volatility of the Slovenian political parties

\begin{tabular}{|l|l|l|l|l|l|l|l|}
\hline $\begin{array}{l}\text { Poli- } \\
\text { tical } \\
\text { parties }\end{array}$ & \multicolumn{1}{|c|}{$\begin{array}{c}\mathbf{1 9 9 2}- \\
\mathbf{1 9 9 6}\end{array}$} & $\begin{array}{c}\mathbf{1 9 9 6 -} \\
\mathbf{2 0 0 0}\end{array}$ & $\begin{array}{c}\mathbf{2 0 0 0 -} \\
\mathbf{2 0 0 4}\end{array}$ & $\begin{array}{c}\mathbf{2 0 0 4 -} \\
\mathbf{2 0 0 8}\end{array}$ & $\begin{array}{c}\mathbf{2 0 0 8 -} \\
\mathbf{2 0 1 1}\end{array}$ & $\begin{array}{c}\mathbf{2 0 1 1 -} \\
\mathbf{2 0 1 4}\end{array}$ & $\Sigma$ \\
\hline LDS & $(+) 1,78$ & $(+) 4,63$ & $(-) 6,73$ & $(-) 8,80$ & $(-) 1,87$ & - & 4,76 \\
\hline SLS & $(+) 5,35$ & $(-) 4,92$ & $(-) 1,36$ & $(-) 0,81$ & $(+) 0,81$ & $(-) 1,44$ & 2,49 \\
\hline SDS & $(+) 6,40$ & $(-) 0,16$ & $(+) 6,64$ & $(+) 0,09$ & $(-) 1,54$ & $(-) 2,74$ & 2,93 \\
\hline DeSUS & - & $(+) 0,43$ & $(-) 0,57$ & $(+) 1,71$ & $(-) 0,24$ & $(+) 1,61$ & 0,91 \\
\hline SNS & $(-) 3,40$ & $(+) 0,59$ & $(+) 0,94$ & $(-) 0,44$ & $(-) 1,80$ & $(+) 0,20$ & 1,23 \\
\hline SD & $(-) 2,28$ & $(+) 1,53$ & $(-) 0,96$ & $(+) 10,14$ & $(-) 9,97$ & $(-) 2,27$ & 4,53 \\
\hline NSi & $(-) 2,45$ & $(-) 0,48$ & $(+) 0,22$ & $(-) 2,85$ & $(+) 0,74$ & $(+) 0,36$ & 1,18 \\
\hline $\begin{array}{l}\text { Total } \\
\text { volati- } \\
\text { lity }\end{array}$ & 3,61 & 1,82 & 2,49 & 3,55 & 2,42 & 1,44 & 2,56 \\
\hline
\end{tabular}

Source: author's own counting according to the official electoral results (www. dvk-rs.si)

Similarly as in the Czech Republic, also in the Slovenia the fluctuating values of voter volatility can be noticed. At first sight it is obvious that LDS is the least institutionalized political party and reaches an average value of voter volatility of $4.76 \%$, which is the highest value of the volatility of all observed Czech and Slovenian political parties. The support and volatility of the LDS party greatly varies in historical perspective. As an interesting fact, we can say that in 1992 the party reached the support of $23.46 \%$ of the votes and in 2011 , only $1.48 \%$ of the votes. When looking at the table it can be stated that until the year 2000, the electoral support of the party rose steadily. After the elections in 2004, there had only fallen, that impacted the volatility which reached a high value of $8.80 \%$ in 2004-2008. Similar average volatility can be noticed in the parties SLS and SDS. It can be generally said that the most regular electoral support of SLS party was in the years 2004-2011, the support of SDS was the most regular 
in 2004-2008, when the lowest voter volatility within the individual political parties was noticed, because the electoral support of the party has changed in this period only by $0.18 \%$ of the votes. The most institutionalized party in the Slovenian system is undoubtedly DeSUS. More significant fluctuations are not noted, so it is not necessary to pay more attention to it. A similar trend is also apparent in the SNS party for which the typical volatility is below $1 \%$, apart from two election series. The second place in the ranking of the least institutionalized parties belongs to the SD party, which reached the highest values of voter volatility caused by the increase in the electoral support of $20.28 \%$ of the votes in 2004-2011 followed by the decline in the support of $19.93 \%$ of the votes. Based on this fact, one can say that it was the SD party who suffered the most in connection with the start of new entities on the political scene in 2011 and with their unexpected success. When we look at the chart, another interesting fact can be found. That is the fact that the success of the new political parties in the 2014 elections did not affect any particular party as much as in 2011, because the volatility of individual parties does not exceed $2.8 \%$. For this reason, we can say that there has been more or less uniform electoral support moving towards the new political entities. The last observed party is the NSi party which does not have any major fluctuations in a historical perspective and belongs to the second most institutionalized party. When comparing with the table of stability indicator of party competition, the observed Slovenian political parties reached the score of 3, with an average volatility of $2.56 \%$. As in case of the Czech Republic, it can be said also here that the Slovenian party system is fully institutionalized in terms of volatility despite the entry of the new entities on the political scene.

\section{THE QUALITY OF PARTY COMPETITION}

In determining the level of institutionalization of party systems we consider the quality of party competition, apart from the above criteria, that belongs to external criteria and in our opinion it is also important for the institutionalization of party systems. Under this criterion we also take into account the regularity of elections, mainly because the irregularity of elections or rather the announcement of early elections is for both countries typical. In the case of the Czech Republic, six parliamentary elections to the Chamber of Deputies has taken place since 1996. If we look at the regularity of elections, one must say that in this respect the country does not show the highest score because two early elections has been announced since 1996, specifically in 1998 and 2013. In comparison with the indicator of elections regularity table the Czech Republic shows the gain of 2 points. On this basis one can conclude that the Czech party system achieves the middle level of 
institutionalization according to the overall indicator of party competition.

In Slovenia, seven parliamentary elections have taken place since 1992. Regarding early elections, Slovenia was confronted with this situation twice, in 2011 and 2014. On this basis, similarly to the Czech Republic, we come to the result of 2 points, which corresponds to the middle level of institutionalization.

\section{SUMMARY AND EVALUATION OF THE SITUATION IN TERMS OF INSTITUTIONALIZATION OF THE PARTY SYSTEM}

In the previous paragraphs of this article we try to apply our selected subindicators measuring the institutionalization on the examples of the Czech and Slovenian parliamentary political parties. Based on our research we have obtained the following results. One achieved the overall level of institutionalization of the party systems by counting up and averaging them.

Table 8: The overall level of institutionalization of the Czech party system

\begin{tabular}{|l|l|l|l|l|}
\hline & Incorporation & Stability & Quality & Average \\
\hline Indicators & 2,25 & 3 & 2 & 2,42 \\
\hline
\end{tabular}

Source: author's own calculation

As one can see, the average of the indicators set above has the value of 2.42. According to that we can talk about the middle level of institutionalization of the Czech party system. We can generally say that the Czech party system is characterized by the stability, the only significant problem in recent years is the formation of new political parties and their success in elections. As we have mentioned several times, the success of new political parties is connected with dissatisfaction of Czech public with the political situation and also with the conviction of the Czech citizens about the widespread corruption among public officials. When looking at the chart we see that the indicator of incorporation of political parties in the party system achieves low values. Within this indicator an analysis of electoral support for parliamentary political parties and support for the so-called presidential outsiders was conducted. In case of support of parliamentary parties, the reason for this may be found again in good results of the new entities which began to appear on the political scene especially before the elections in 2010 and 2013, and thus in the decline of the electoral support for the established political parties. Regarding the support of presidential outsiders, based on the election results, we can state that the Czech public does not consider 
the party membership of the candidate and does not vote him by the success of representing the party in the elections, which is documented by the fact that outsiders had dominance in the presidential election in 2013.

The highest score in case of stability of party competition affirms the fact of the long-term functioning of political partisanship and competition. In our analysis, we have also incorporated an external indicator which is the quality of party competition. Due to the already two announced early elections, this indicator suggests a lower degree of institutionalization. Overall, we can say that the Czech party system can face various obstacles in the form of new political entities and can maintain its stability. But the question remains whether this claim is true in the future.

Similarly to the Czech Republic, we also conducted an analysis of the Slovenian party system and based on the same indicators we obtained the following results.

\section{Table 9: The overall level of institutionalization of the Slovenian party system}

\begin{tabular}{|l|l|l|l|l|}
\hline & Incorporation & Stability & Quality & Average \\
\hline Indicators & 2,25 & 3 & 2 & 2,42 \\
\hline
\end{tabular}

Source: author's own calculation

Individual partial indicators and their average suggest that for the Slovenian party system, it is possible to talk about the middle level of institutionalization. As one can see, various indicators reach the same values as in the Czech party system. The analysis of the electoral support of the parliamentary parties showed us that in the last two elections a resolute change in the Slovenian political scene has occurred. The reason for this was the departure of voters from the traditional parties towards the new entities. The more detailed investigation of the election results displays that the voter support of the Slovenian political parties with a long-term parliamentary representation since 2008 has fallen by $37.77 \%$. One can generally say that this decline of votes and distrust of voters against the established political parties was primarily caused by internal crises and corruption scandals. The overall result of incorporation indicator also influenced the scoring of a partial indicator of support for the presidential outsiders. Due to analyzing the election results of the presidential election, one can now conclude that the support of the outsiders exceeds the support of the candidates of the parliamentary parties. The reason for this claim is the fact that during five 
elections, the third candidate of a non-parliamentary political party achieved the best overall result. For this reason, it is believed that neither Slovenian voters do not consider the party membership of the presidential candidate. The middle level of institutionalization was reached by the Slovenian party system also for the quality of party competition. The announcement of two early parliamentary elections has an impact on this result. Similarly to the Czech party system, also the Slovenian one has reached the highest score in case of the indicator of the party competition stability. One can therefore conclude that despite the entry of the new entities to the political scene from the perspective of volatility, the Slovenian system is fully institutionalized. Based on the above mentioned facts, one has to add that the Slovenian party system is institutionalized to the same extend as the party system of the Czech Republic. Even here, one can say that the future form of the Slovenian party system is in these days very difficult to estimate. The following elections will show whether the trend of success of the new political entities, the decline in the electoral support of the established parliamentary parties or the announcement of early elections will continue.

\section{CONCLUSION}

Based on the above mentioned facts, one can now say that in the Czech Republic and the Republic of Slovenia, a number of very similar phenomena may be observed in the last two decades. First, it must be emphasized that the party systems of the two countries were characterized by fair stability for a long time. They belong to the best ones, compared with the other post-communist countries in the Central European region. In the last few years, in both cases there was a break caused by the success of new political entities on the Czech and Slovenian political scene. Despite this fact it cannot be argued that the stability of the Czech and Slovenian party system was disrupted. The existing bases of the party systems of the observed countries maintained their positions, though not with as much voter support. The reason for this claim is the fact that in case of the Czech Republic, only TOP 09 maintained its parliamentary representation in the next elections. In Slovenia, none of the newly formed parties did so. But the future will show whether such a finding is appropriate, as it is now supported by only by one election results.

One can say that despite the interventions of smaller newly formed political parties trying to destabilize the party system, the party systems still remained institutionalized. In the future, in this author's opinion, it is interesting to investigate whether the trend of new smaller political parties will disappear or the new entities which will not last for a long time and will vary among themselves 
will still come. Another possibility is that some of the small parties, acquires its significance and becomes a part of the Czech and Slovenian institutionalized party system. It is still a question of discussions and forecasts which gives us a definitive answer in the future.

The topic of party systems is quite extensive so it is not possible to take all factors affecting the issue into account. As important, one may consider more detailed dealing with various factors that affect the stability of party systems, or applying our proposed research framework on other countries. In our opinion, it would be very interesting to take into account the evolution of party systems in other post-communist countries and thus to conclude whether the tendency of the decline of the main political parties on the political scene and the rise of the new entities is random in case of the Czech Republic and the Republic of Slovenia, or if this trend is typical for all post-communist countries. This question as well as the question of possible limits of individual criteria within the indicator will need further and deeper investigation.

\section{REFERENCES}

CABADA, Ladislav, HLOUŠEK, Vít, JUREK, Petr. 2013. Ztraceny $v$ tranzici? Minulost a prítomnost politického stranictví ve středni a východní Evropě. Brno: Masarykova univerzita, Fakulta sociálních studií, Mezinárodní politologický ústav.

CARBONE, Giovanni M. 2007. Political Parties and Party Systems in Africa: Themes and Research Perspectives. World Political Science Review, vol. 2, no. 3 , p. 1-29.

FIALA, Vlastimil. 2015. Institucionalizace mosambických politických stran a stranického systému. Olomouc: Iuridicum Olomoucense.

KUENZI, Michelle, LAMBRIGHT, Gina. 2001. Party System Institutionalization in 30 African Countries. Party Politics, vol. 7, no. 4, p. 437-468.

MAINWARING, Scott, TORCAL, Mariano. 2006. Party System Institutionalization and Party System Theory After the Third Wave of Democratization. In KATZ, S. Richard, CROTTY, William (eds.). Handbook of Party Politics. London: Sage.

MAINWARING, Scott. 1999. Rethinking Party Systems in the Third Wave of Democratization. The Case of Brazil. Stanford: Stanford University Press.

SARTORI, Giovanni. 2005. Strany a stranické systémy: schéma pro analýzu. 
Brno: Centrum pro studium demokracie a kultury.

STRMISKA, Maxmilián. 2000. Scott Mainwaring a teorie stranických systémů ve třetí vlně demokratizace. Několik podnětů $k$ diskusi [online]. cepsr. com [retrieved from March 25, 2016]. From <http://www.cepsr.com/clanek. php?ID $=134>$.

ŠEDO, Jakub. 2011. Vybrané problémy kvantitativního výzkumu stability stranických systémů a jejich možná řešení. European Electoral Studies, vol. 6, no. 1 , s. 63-74. 